\title{
Orta ve Geçit Bölgelerine Uygun Kılçıksız Brom (Bromus inermis Leyss ) Çeşitlerinin Geliştirilmesi
}

\author{
Yaşar KARADAĞ $\breve{S}^{1}$ \\ Sezai GÖKALP3 \\ Tahsin TAŞYÜREK ${ }^{3}$ \\ Rüştü HATIPOĞLU ${ }^{4}$ \\ ${ }^{1}$ Gaziosmanpaşa Üniversitesi, Ziraat Fakültesi, Tarla Bitkileri Bölümü, Tokat \\ ${ }^{2}$ KTMU Ziraat Fakültesi Kırgizistan/ Kilis 7 Aralık Üniversitesi, TBMYO Kilis \\ ${ }^{3}$ Orta Karadeniz Geçit Kuşağı Tarımsal Araştırma İstasyonu Müdürlüğü, Tokat \\ ${ }^{4}$ Çukurova Üniversitesi, Ziraat Fakültesi, Tarla Bitkileri Bölümü, Adana \\ $\bowtie$ : scinar01@hotmail.com
}

Geliş (Received): 02.11.2017

Kabul (Accepted): 15.12.2017

\begin{abstract}
ÖZET: Bu araştırma, 2013-2015 yılları arasında Tokat ve Sivas ekolojik koşullarında bazı kılçıksız bromun (Bromus inermis) çeşit adaylarının ot verimi ve ot kalitesini belirlemek amacıyla yürütülmüştür. Araştırmada, iki çeşit adayı ve iki popülasyon, materyal olarak kullanılmıştır. Denemeler iki lokasyonda (Tokat Orta Karadeniz Geçit Kuşağı Tarımsal Araştırma İstasyonu Müdürlüğü, Sivas-Şarkışla Yem Bitkileri Üretim İstasyonu), dört tekrarlamalı, tesadüf blokları deneme desenine uygun olarak yürütülmüştür. Araştırmanın sonuçları, incelenen populasyon ve çeşit adaylarının ot verimlerinin ve kalitelerinin önemli derecede farklılık gösterdiğini ortaya koymuştur. İki yıllık ortalamalara göre, Tokat ve Sivas lokasyonunda sırasıyla en yüksek bitki boyu $(68.90,130.2 \mathrm{~cm})$, yaş ot verimi (3129.0, $\left.3634.8 \mathrm{~kg} \mathrm{da}^{-1}\right)$ ve kuru ot verimi $\left(1233.0,1210.4 \mathrm{~kg} \mathrm{da}^{-1}\right) 2$ nolu çeşit adayında, ham protein oranı (\% $13.22,12.81)$, ham protein verimi $\left(149.9 \mathrm{~kg} \mathrm{da}-1,145.9 \mathrm{~kg} \mathrm{da}^{-1}\right)$ ise 1 nolu çeşit adayında belirlenmiştir. 2 nolu çeşit adayı verim, 1 nolu çeşit adayı ise kalite yönü ile öne çıkmıştır. Her iki çeşit adayı 2016 yılı içerisinde tescil edilmek üzere TTSM'ye sunulmuştur.
\end{abstract}

Anahtar Kelimeler: Kılçıksız brom, bitki boyu, ham protein oranı, verim

\section{Development of Smoooth Brome Cultivars for the Middle and Transition Regions of Turkey}

ABSTRACT: This study was carried out to determine the hay yields and qualities of cultivar canditates of smooth brome under Tokat and Sivas ecological conditions during the years of 2013-2015. In the study, two cultivar canditates and two populations of smooth brome were used as plant material. The field trial was designed according to a randomized block design with four replications in the research areas of Central Black Sea Transition Zone Agricultural Research Institute Directorate in Tokat and in Sivas-Sarkisla. Results of the study showed that materials tested were significantly different in hay yield and quailty. One of the cultivar canditates was the superior in hay yield and the other cultivar canditate in hay quality. From the results of the study, it was concluded that both of candidates could be submitted to the TTSM for registration .

Key Words: Smooth brome, plant height, crude protein ratio, hay yield

\section{GíRIŞ}

Ülkemizde son yillarda yem bitkileri tohumculuğunda önemli gelişmeler olmasına rağmen aynı gelişme çok yıllık mera türlerinin tohumculuğunda sağlanamamıştır. Ülkemiz topraklarının \% 20'sini kaplayan ve ülkemiz hayvancılığı açısından büyük önem taşıyan çayır-meralarımızın tekniğine uygun olmayan otlatma ve biçim nedeniyle büyük ölçüde bitki örtülerini kaybettikleri için tohumlama yöntemiyle sslah edilmesi gerekmektedir. Meralarımızın ıslahında kullanılmak üzere ülkemizin farklı ekolojik koşullarına uygun, verimli ve kaliteli ot üreten yem bitkisi tür ve çeşitlerinin geliştirilmesi ve bunların tohumlarının yeterli miktarda üretilmesi gerekmektedir. Çok farklı ekolojik bölgelere sahip olan ülkemiz bir çok yem bitkisi türünün gen merkezi olmasına ve yem bitkisi tohumculuğu için çok uygun ekolojik koşullara sahip olmasına karşılık ıslah edilmiş çok yıllık yem bitkisi çeşidi çok az sayıdadır. Mera tesislerinde kullanılan tür ve çeşitler genel olarak yurt dışından ithal edilmekte ve milyonlarca dolar döviz ödenmektedir. Yurtdışından ithal edilen mera bitkisi tohumlarının miktarını net olarak belirten bir kayıt olmamasına rağmen ithal edilen yem bitkisi, çim ve çayır otu tohumluk miktarını gösteren veriler elde mevcuttur. 2002 yılında yem bitkisi, çim ve çayır otu ithalatı tohumluk miktarı 2.534 ton iken ithal edilen miktar yıllar içerisinde artmış 2010 yılında 4.627 tona, 2016 yilında ise 11.152 tona ulaşmıştır. Belirtilen bu tohumluk miktarının parasal değeri 2002 yılında 3.473.000, 2010 yılında 8.670.000 \$, 2016 yılında ise 20.683.000 \$' dir (GTHB, 2017). Ayrıca ithal edilen bu tohumların kullanıldıkları alanları ekolojik koşullarına tam olarak adapte olamadıkları için çoğu kez mera tesis çalışmaları başarısız olmuştur.

Kaba yem açığının kapatılmasında meralar önemli bir yere sahiptir. Mera ıslahında kullanılmak üzere çok yıllık buğdaygil ve baklagil yem bitkisi çeşitlerinin islah edilmesi ve bunların tohumlarının yeterli miktarda üretilmesi ile bir gen merkezi olan ülke kaynaklarından yerinde kullanım sağlanmış olacak ve ithalat yoluyla ülke dışına gitmekte olan kaynak kaybı önlenecektir. 
Kılçıksız brom meraların temel bitkisidir. Bitki örtüsünü ve dolayısıyla verim gücünü kaybetmiş meraların yeniden sslah edilmesi ve 4342 sayıl mera kanununun 5-b maddesine göre tesbit ve tahditi yapılan mera alanlarının ve özel meraların tesisinde kılçıksız brom büyük bir öneme sahiptir. Yürütülen birçok araştırmada kılçıksız bromun ülkemiz koşullarında çayır ve mera tesisinde kullanılabileceği ortaya konulmuştur (Tosun 1974; Gökkuş, 1987; Serin ve Tan, 2009).

$\mathrm{Bu}$ araştırma ile, orta ve geçit bölgelerine uygun, kılçıksız brom çeşit adaylarının ot verimi ve kalitelerinin belirlenerek tescile sunulması amaçlanmıştır.

\section{MATERYAL ve YÖNTEM}

$\mathrm{Bu}$ araştırma, 2013 - 2015 yılları arasında iki yıl süreyle Orta Karadeniz Geçit Kuşağı Tarımsal Araştırma İstasyonu Müdürlüğü'nün Tokat ve SivasŞarkışla'da bulunan deneme alanlarında yürütülmüştür. Denemelerde Sivas ve Tokat meralarından toplanan kılçıksız brom popülasyonlarından toptan seleksiyon yöntemi ile selekte edilerek geliştirilen her birisi 20 klondan oluşan iki adet kılçıksız brom çeşit adayı ile TİGEM popülasyonu ve Erzurum tohum 1slah populasyonu materyal olarak kullanılmıştır. Gaziosmanpaşa Üniversitesi Ziraat Fakültesi Toprak Analizi Laboratuarında yapılan analiz sonuçlarına göre her iki deneme alanı toprakları; killi tınlı, tuzsuz, hafif alkali, bitkiler tarafindan alınabilir fosfor ve potasyum yönünden zengin, organik madde ve kireç bakımından orta düzeyde bir toprak özelliğine sahiptir (Aydeniz ve Brohi, 1991). Meteoroloji Genel Müdürlüğü verilerine göre, araştırmanın yürütüldüğü yıllar ve uzun yıllar aylık sicaklık ortalaması Tokat lokasyonunda, 12.2, 13.4 ve $12.5^{\circ} \mathrm{C}$, Sivas lokasyonunda; $9,0,10.2$ ve $9.3^{\circ} \mathrm{C}$, aylık toplam yağıș miktarı Tokat lokasyonunda 267.5, 399.3 ve $443.7 \mathrm{~mm}$, Sivas lokasyonunda $242.3,312.3$ ve 385.5 $\mathrm{mm}$ ve ortalama nispi nem oranı ise Tokat lokasyonunda, $\%$ 66.4, \% 68.6 ve $\%$ 62.5, Sivas lokasyonunda ise $\% \quad 63.4,62.0$ ve 62.3 olarak kaydedilmiştir. Buna göre deneme yıllarının uzun yıllardan daha az yağışlı geçtiğini söyleyebiliriz.

Çeşit adayları ve popülasyonların her birisi $40 \mathrm{~cm}$ aralıklı $5 \mathrm{~m}$ uzunluğundaki 8 sıradan oluşan parsellere ekilmiştir. Ekimde tohumluk miktarı $2.0 \mathrm{~kg} \mathrm{da}^{-1}$ olarak alınmış ve ekim öncesi parsellere $10 \mathrm{~kg} \mathrm{da}^{-1}$ saf azot, 5 $\mathrm{kg} \mathrm{da}^{-1}$ saf fosforlu gübre uygulanmıştır (Anonim, 2001). Denemeler her iki lokasyonda 4 tekrarlamalı, tesadüf blokları deneme desenine uygun olarak kurulmuştur. Hasat; salkım başlangıcı döneminde yapılmıștır. Hasatta her parselde yanlardan birer sıra ve parsel başı ile sonundan 0.5 m'lik kısım kenar tesiri olarak biçilip atıldıktan sonra, geriye kalan $4 \mathrm{~m}$ uzunluğundaki 6 sıra biçilmiştir. 2013 y1lı tesis y1lı olduğundan dolayı kök gelișimi amacıyla herhangi bir hasat yapılmamıştır. Her iki lokasyonda her yıl ikişer biçim yapılmıştır. Her parselden alınan 500 gr ot örneği $70{ }^{\circ} \mathrm{C}$ 'ye ayarlanmıs firında 24 saat kurutulduktan sonra tartılmıştır. Bu örnekler kalite analizleri için $1 \mathrm{~mm}$ 'lik elekten geçecek şekilde ögütüldükten sonra, Kjeldahl cihazıyla örneklerin azot içeriği saptanmış, saptanan azot değerleri 6.25 katsayısı ile çarpılarak ham protein oranı değerleri hesaplanmıștır.

Her parselde; bitki boyu, yaş ot verimi, kuru ot verimi ve ham protein oran1, Anonim (1995), Anonim (2001) ve Şehirali (2002) tarafindan açıklanan yöntemlere göre saptanmıştır. Araştırmadan elde edilen verilerin değerlendirilmesinde, MSTAT-C istatistik paket programı kullanılarak tesadüf blokları deneme desenine uygun olarak varyans analizi uygulanmıștır. Varyans analizi sonuçlarına göre istatistiksel olarak önemli çıkan faktör ortalamaları LSD testi ile karşılaştırılmıştır (Düzgüneş ve ark. 1987).

\section{BULGULAR ve TARTIŞMA}

Bitki Boyu: Araştırmada incelenen çeşit adayı ve populasyonların bitki boyu Çizelge 1'de verilmiştir.

Çizelge 1. Araştırmada incelenen kılçıksız brom materyalinde bitki boyu ortalamaları $(\mathrm{cm})$

\begin{tabular}{|l|c|c|c|}
\hline \multirow{2}{*}{ Çeşit adayı ve populasyonlar } & \multicolumn{3}{|c|}{ Ana Sap Uzunluğu (cm) } \\
\cline { 2 - 4 } & \multicolumn{3}{|c|}{ Tokat Lokasyonu } \\
\cline { 2 - 4 } & $\mathbf{2 0 1 4}$ & $\mathbf{2 0 1 5}$ & Ortalama \\
\hline Çeşit adayı1 1 & $65.0 \mathrm{bc}^{*}$ & $59.1 \mathrm{~b}$ & $62.1 \mathrm{~b}$ \\
\hline Çeşit adayı1 2 & $74.1 \mathrm{a}$ & $63.7 \mathrm{a}$ & $68.9 \mathrm{a}$ \\
\hline Tigem Populasyonu & $72.6 \mathrm{ab}$ & $62.1 \mathrm{a}$ & $60.3 \mathrm{c}$ \\
\hline Erzurum Islah populasyonu & $61.2 \mathrm{c}$ & $59.3 \mathrm{~b}$ & 64.7 \\
\hline Ortalama & $68.2 \mathrm{~A}^{* *}$ & $61.1 \mathrm{~B}$ & $124.8 \mathrm{~b}$ \\
\hline \multicolumn{3}{|c|}{ Sivas Lokasyonu } \\
\hline Çeşit aday1 & $126.4 \mathrm{a}^{*}$ & $123.2 \mathrm{~b}$ & $130.2 \mathrm{a}$ \\
\hline Çeşit adayı 2 & $128.5 \mathrm{a}$ & $131.9 \mathrm{a}$ & $124.5 \mathrm{~b}$ \\
\hline Tigem Populasyonu & $120.7 \mathrm{~b}$ & $128.2 \mathrm{a}$ & $116.5 \mathrm{c}$ \\
\hline Erzurum Islah populasyonu & $114.3 \mathrm{c}$ & $118.7 \mathrm{c}$ & 124.0 \\
\hline Ortalama & $122.5 \mathrm{~B} * *$ & $125.5 \mathrm{~A}$ & \\
\hline
\end{tabular}

*Aynı sütun içerisinde benzer harf ile gösterilen ortalamalar, LSD testine göre, $\mathrm{P} \leq 0,05$ hata sınırları içerisinde birbirlerinden farksızdır. **Aynı satır içerisinde benzer harf ile gösterilen ortalamalar $\mathrm{P} \leq 0,01$ hata sınırları içerisinde birbirlerinden farksızdır 
Çizelge 1'de görüldüğü üzere her iki lokasyonda çeşit adayı ve populasyonlar ile yıllar bitki boyunda istatistiki olarak önemli farklar yaratmıştır. Her iki lokasyonda en yüksek bitki boyu 2 nolu çeşit adayında belirlenmiştir. Tokat lokasyonunda ortalama bitki boyu $64.7 \mathrm{~cm}$ iken Sivas lokasyonunda $124.0 \mathrm{~cm}$ olarak gerçekleşmiştir. Kılçıksız bromda bitki boyunu Serin ve ark. (1996) 81.2-109.2 cm, Karakurt ve Ekiz (2000) $96.1 \mathrm{~cm}$ olarak bildirmişlerdir. Araştırmadan elde edilen bitki boyu her iki lokasyonda da, Serin ve ark. (1996), Karakurt ve Ekiz (2000)'in bulguları ile de oldukça farklıdır. Bunun nedeninin ekoloji, bakım ve çeşit farklılıklarından kaynaklanmış olabileceğini söyleyebiliriz.

Yaş Ot Verimi: Araştırmada incelenen çeşit adayı ve populasyonların yaş ot verimleri ortalama değerleri Çizelge 2'de verilmiştir.

Çizelge 2. Araştırmada incelenen kılçıksız brom materyalinin yaş ot verimi ortalamaları $\left(\mathrm{kg} \mathrm{da}^{-1}\right)$

\begin{tabular}{|l|c|c|c|}
\hline \multirow{2}{*}{ Çeşit adayı ve populasyonlar } & \multicolumn{3}{|c|}{ Tokat Lokasyonu } \\
\cline { 2 - 4 } & $\mathbf{2 0 1 4}$ & $\mathbf{2 0 1 5}$ & Ortalama \\
\hline Çeşit adayı 1 & $3171.1 \mathrm{~b}$ & $2579.3 \mathrm{bc}$ & $2875.2 \mathrm{~b}^{*}$ \\
\hline Çeşit adayı 2 & $3478.0 \mathrm{a}$ & $2779.9 \mathrm{a}$ & $3129.0 \mathrm{a}$ \\
\hline Tigem Populasyonu & $3243.6 \mathrm{~b}$ & $2715.1 \mathrm{ab}$ & $2979.3 \mathrm{~b}$ \\
\hline Erzurum Islah populasyonu & $2893.7 \mathrm{c}$ & $2510.7 \mathrm{c}$ & $2702.2 \mathrm{c}$ \\
\hline Ortalama & $3196.6 \mathrm{~A}^{* *}$ & $2646.2 \mathrm{~B}$ & 2921.4 \\
\hline \multicolumn{3}{|c|}{ Sivas Lokasyonu } \\
\hline Çeşit adayı 1 & $3428.1 \mathrm{~b}$ & $3203.1 \mathrm{c}$ & $3315.6 \mathrm{c}$ \\
\hline Çeşit adayı 2 & $3634.4 \mathrm{a}$ & $3635.2 \mathrm{a}$ & $3634.8 \mathrm{a}$ \\
\hline Tigem Populasyonu & $3428.1 \mathrm{~b}$ & $3487.6 \mathrm{~b}$ & $3457.9 \mathrm{~b}$ \\
\hline Erzurum Islah populasyonu & $3148.1 \mathrm{c}$ & $3165.3 \mathrm{c}$ & $3156.7 \mathrm{~d}$ \\
\hline Ortalama & $3409.7 \mathrm{~A} * *$ & $3372.8 \mathrm{~B}$ & 3391.3 \\
\hline
\end{tabular}

${ }^{*}$ Aynı sütun içerisinde benzer harf ile gösterilen ortalamalar, LSD testine göre, $\mathrm{P} \leq 0,05$ hata sınırları içerisinde birbirlerinden farksızdır. **Aynı satır içerisinde benzer harf ile gösterilen ortalamalar $\mathrm{P} \leq 0,01$ hata sınırları içerisinde birbirlerinden farksızdır.

Çizelge 2'de görüldüğü üzere her iki lokasyonda çeşit adayı ve populasyonlar ile yıllar, yaş ot verimlerinde istatistiki olarak önemli farklar yaratmıştır. Her iki lokasyonda en yüksek yaş ot verimi 2 nolu çeşit adayında saptanmıştır. Tokat lokasyonunda ortalama yaş ot verimi $2921.4 \mathrm{~kg} \mathrm{da}^{-1}$ iken Sivas lokasyonunda $3391.3 \mathrm{~kg} \mathrm{da}^{-1}$ olarak gerçekleşmiştir. Kılçıksız bromda yaş ot verimini Smith (1981) 267.5-1005 $\mathrm{kg} \mathrm{da}^{-1}$,
Karakurt ve Ekiz (2000) $1868.3 \quad \mathrm{~kg} \quad \mathrm{da}^{-1}$ olarak bildirmişlerdir. Her iki lokasyondan elde edilen yaş ot verimi Smith (1981) ve Karakurt ve Ekiz (2000) ile uyumlu değildir. Bunun nedeninin ekoloji, bakım ve çeşit farklılığından kaynaklandığını söyleyebiliriz.

Kuru Ot Verimi: Araştırmada incelenen kılçıksız brom materyalinin kuru ot verimleri ortalama değerleri Çizelge 3'de verilmiştir.

Çizelge 3. Araştırmada incelenen kılçıksız brom materyalinin kuru ot verimi ortalamaları $\left(\mathrm{kg} \mathrm{da}^{-1}\right)$

\begin{tabular}{|l|c|c|c|}
\hline \multirow{2}{*}{ Çeşit adayı ve populasyonlar } & \multicolumn{3}{|c|}{ Tokat Lokasyonu } \\
\cline { 2 - 4 } & 2014 & 2015 & Ortalama \\
\hline Çeşit aday1 1 & $1326.7 \mathrm{bc} *$ & $941.4 \mathrm{~b}$ & $1134.1 \mathrm{~b}$ \\
\hline Çeşit adayı 2 & $1479.2 \mathrm{a}$ & $986.8 \mathrm{~b}$ & $1233.0 \mathrm{a}$ \\
\hline Tigem Populasyonu & $1442.4 \mathrm{ab}$ & $941.5 \mathrm{~b}$ & $1192.0 \mathrm{~b}$ \\
\hline Erzurum Islah populasyonu & $1224.0 \mathrm{c}$ & $1058.9 \mathrm{a}$ & $1141.5 \mathrm{~b}$ \\
\hline Ortalama & $1368.1 \mathrm{~A}^{* *}$ & $982.2 \mathrm{~B}$ & 1175.2 \\
\hline \multicolumn{3}{|c|}{ Sivas Lokasyonu } \\
\hline Çeşit adayı 1 & $1234.1 \mathrm{~b}^{*}$ & $1044.2 \mathrm{c}$ & $1139.2 \mathrm{~b}$ \\
\hline Çeşit adayı 2 & $1308.4 \mathrm{a}$ & $1112.3 \mathrm{~b}$ & $1210.4 \mathrm{a}$ \\
\hline Tigem Populasyonu & $1133.4 \mathrm{~b}$ & $1150.3 \mathrm{a}$ & $1141.9 \mathrm{~b}$ \\
\hline Erzurum Islah populasyonu & $1234.1 \mathrm{c}$ & $956.1 \mathrm{~d}$ & $1095.1 \mathrm{c}$ \\
\hline Ortalama & $1227.5 \mathrm{~A} * *$ & $1065.7 \mathrm{~B}$ & 1146.7 \\
\hline
\end{tabular}

*Aynı sütun içerisinde benzer harf ile gösterilen ortalamalar, LSD testine göre, $\mathrm{P} \leq 0,05$ hata sınırları içerisinde birbirlerinden farksızdır. **Aynı satır içerisinde benzer harf ile gösterilen ortalamalar $\mathrm{P} \leq 0,01$ hata sınırları içerisinde birbirlerinden farksızdır.

Çizelge 3 'de görüldüğü üzere her iki lokasyonda çeşit aday ve populasyonlar ile yıllar, kuru ot verimlerinde istatistiki olarak önemli farklar yaratıışıtır. Her iki lokasyonda en yüksek kuru ot verimi 2 nolu çeşit adayında saptanmıştır. Tokat lokasyonunda ortalama kuru ot verimi $1175.2 \mathrm{~kg} \mathrm{da}^{-1}$ iken Sivas lokasyonunda $1146.7 \mathrm{~kg} \mathrm{da}^{-1}$ olarak gerçekleşmiş̧ir. Kılçıısız bromda kuru ot verimini Larson ve ark. (1971) 
238.0-708.0 kg da-1 , George ve ark. (1973) 91.0-237.2 $\mathrm{kg} \mathrm{da}{ }^{-1}$, Altın (1982) 337.3-720.5 kg da-1, Holt ve Zentner (1985) 157.0-418.0 kg da ${ }^{-1}$, Karakurt ve Ekiz (2000) $662.5 \mathrm{~kg} \mathrm{da}^{-1}$ olarak bildirmişlerdir. Araştırmadan elde edilen kuru ot verimi yukarıda belirtilen literatürlerden daha yüksektir. Bunun nedeninin ekoloji, bakım ve çeşit farklılığından kaynaklandığını söyleyebiliriz.

Ham Protein Oranı: Araştırmada incelenen kılçıksız brom materyalinin ham protein oranı ortalama değerleri Çizelge 4'de verilmiştir.

Çizelge 4. Araştırmada incelenen kılçıksız brom materyalinin ham protein oranı ortalama değerleri (\%)

\begin{tabular}{|l|c|c|c|}
\hline \multirow{2}{*}{ Çeşit aday1 ve populasyonlar } & \multicolumn{3}{|c|}{ Tokat Lokasyonu } \\
\cline { 2 - 4 } & 2014 & 2015 & Ortalama \\
\hline Çeşit aday1 1 & $13.27 \mathrm{a}$ & $13.17 \mathrm{a}$ & $13.22 \mathrm{a}$ \\
\hline Çeşit aday1 2 & $12.01 \mathrm{bc}$ & $11.58 \mathrm{bc}$ & $11.80 \mathrm{~b}$ \\
\hline Tigem Populasyonu & $12.44 \mathrm{~b}$ & $11.30 \mathrm{c}$ & $11.43 \mathrm{~b}$ \\
\hline Erzurum Islah populasyonu & $11.76 \mathrm{c}$ & $11.10 \mathrm{c}$ & 12.08 \\
\hline Ortalama & $12.37 \mathrm{~A}^{* *}$ & $11.79 \mathrm{~B}$ & $12.81 \mathrm{a}$ \\
\hline \multicolumn{3}{|c|}{ Sivas Lokasyonu } \\
\hline Çeşit aday1 1 & $12.89 \mathrm{a}^{* *}$ & $12.73 \mathrm{a}$ & $11.68 \mathrm{~b}$ \\
\hline Çeşit aday1 2 & $11.90 \mathrm{~b}$ & $11.45 \mathrm{~b}$ & $9.40 \mathrm{c}$ \\
\hline Tigem Populasyonu & $9.69 \mathrm{c}$ & $9.10 \mathrm{c}$ & $9.51 \mathrm{c}$ \\
\hline Erzurum Islah populasyonu & $10.02 \mathrm{c}$ & $9.00 \mathrm{c}$ & 10.85 \\
\hline Ortalama & 11.13 & 10.57 & \\
\hline
\end{tabular}

${ }^{*}$ Aynı sütun içerisinde benzer harf ile gösterilen ortalamalar, LSD testine göre, $\mathrm{P} \leq 0,05$ hata sınırları içerisinde birbirlerinden farksızdır. **Aynı satır içerisinde benzer harf ile gösterilen ortalamalar $\mathrm{P} \leq 0,01$ hata sınırları içerisinde birbirlerinden farksızdır.

Çizelge 4'de görüldüğü üzere Tokat lokasyonunda çeşit adayı ve populasyonlar ile yıllar, ham protein oranlarında istatistiki olarak önemli farklar yaratmışıtır. Sivas lokasyonunda ise çeşit adayı ve populasyonlar istatistiki olarak önemli farklılık göstermiş, yıllar ise ham protein oranında istatistiki olarak önemli fark yaratmamıştır. Her iki lokasyonda en yüksek ham protein oranı 2 nolu çeșit adayında saptanmıștır. Kılçısız bromda ham protein oranını Larson ve ark. (1971) \% 11.0-21.6, George ve ark. (1973) \% 14.4-24.5,
Altın (1982) \% 7.6-10.0, Karakurt ve Ekiz (2000) \% 11.5 olarak tespit etmişlerdir. Araştırmadan elde edilen ham protein oran1, Larson ve ark. (1971), Karakurt ve Ekiz (2000) ile uyumlu, George ve ark. (1973), Altın (1982) ile uyumlu değildir. Bunun nedeninin ekoloji, bakım ve çeşit farklılı̆̆ından kaynaklandığını söyleyebiliriz.

Ham Protein Verimi: Araştırmada incelenen kılçıksız brom materyalinin ham protein verimi ortalama değerleri Çizelge 5'de verilmiştir.

Çizelge 5. Araştırmada incelenen kılçıksız brom materyalinin ham protein verimi ortalama değerleri (\%)

\begin{tabular}{|c|c|c|c|}
\hline \multirow{2}{*}{ Çeşit adayı ve populasyonlar } & \multicolumn{3}{|c|}{ Tokat Lokasyonu } \\
\hline & 2014 & 2015 & Ortalama \\
\hline Çeşit adayı 1 & $176.9 \mathrm{ab}$ & $109.0 \mathrm{~b}$ & $149.9 \mathrm{a}$ \\
\hline Çeşit adayı 2 & $177.7 \mathrm{a}$ & $114.3 \mathrm{a}$ & $146.0 \mathrm{a}$ \\
\hline Tigem Populasyonu & $179.4 \mathrm{a}$ & $106.4 \mathrm{~b}$ & $142.9 \mathrm{a}$ \\
\hline Erzurum Islah populasyonu & $143.9 \mathrm{~b}$ & $117.5 \mathrm{a}$ & $130.7 \mathrm{~b}$ \\
\hline Ortalama & $169.5 \mathrm{~A}^{* *}$ & $111.8 \mathrm{~B}$ & 140.7 \\
\hline \multicolumn{4}{|c|}{ Sivas Lokasyonu } \\
\hline Çeşit adayı 1 & $159.1 \mathrm{a}^{*}$ & $132.9 \mathrm{a}$ & $145.9 \mathrm{a}$ \\
\hline Çeşit adayı 2 & $155.7 \mathrm{a}$ & $127.4 \mathrm{a}$ & $141.5 \mathrm{a}$ \\
\hline Tigem Populasyonu & $109.8 \mathrm{c}$ & $104.7 \mathrm{~b}$ & $107.3 \mathrm{~b}$ \\
\hline Erzurum Islah populasyonu & $123.7 \mathrm{~b}$ & $86.0 \mathrm{c}$ & $104.9 \mathrm{~b}$ \\
\hline Ortalama & $137.1 \mathrm{~A}^{* *}$ & $112.8 \mathrm{~B}$ & 125.0 \\
\hline
\end{tabular}

${ }^{*}$ Aynı sütun içerisinde benzer harf ile gösterilen ortalamalar, LSD testine göre, $\mathrm{P} \leq 0,05$ hata sınırları içerisinde birbirlerinden farksızdır. **Aynı satır içerisinde benzer harf ile gösterilen ortalamalar $\mathrm{P} \leq 0,01$ hata sınırları içerisinde birbirlerinden farksızdı

Çizelge 5'de görüldüğü üzere her iki lokasyonda çeșit adayları ve populasyonlar ile yıllar, ham protein veriminde istatistiki olarak önemli farklar yaratmıștır. Her iki lokasyonda en yüksek ham protein verimi 1 nolu çeşit adayında saptanırken bunu 2 nolu çeşit adayı izlemiş ve 1 nolu çeșit adayı ile aynı grupta yer almıștır.
Ortalama ham protein verimi Tokat lokasyonunda 140.7 $\mathrm{kg} \mathrm{da}^{-1}$ iken Sivas lokasyonunda $125.0 \mathrm{~kg} \mathrm{da}^{-1}$ olarak gerçekleşmiştir. Ham protein verimi, ham protein oranı ile kuru ot verimin çarpılması ile elde edilen bir değer olduğundan dolayı genel olarak verimi ve ham protein 
oranı yüksek olan çeşit adayı ve populasyonların ham protein verimi de yüksek bulunmuştur.

Kılçıksız bromda ham protein verimini Larson ve ark. (1971) 27.6-178.8 $\mathrm{kg} \mathrm{da}^{-1}$, Smith (1981) 40.0-235.0 $\mathrm{kg} \mathrm{da}{ }^{-1}$, Altın (1982) 49.0-120.0 $\mathrm{kg} \mathrm{da}^{-1}$, Karakurt ve Ekiz (2000) $79.1 \mathrm{~kg} \mathrm{da}^{-1}$ olarak bildirmişlerdir. Araştırmadan elde edilen ham protein verimi Larson ve ark. (1971), Smith (1981), Altın (1982) ile uyumlu, Karakurt ve Ekiz (2000) ile uyumlu değildir. Bunun nedeninin ekoloji, bakım ve çeşit farklılığından kaynaklandığgnı söyleyebiliriz.

\section{SONUÇ}

Araştırma sonuçlarına göre, bitki boyu, yaş ot, kuru ot verimlerinde 2 nolu çeşit adayı, ham protein oranı ve ham protein veriminde ise her iki lokasyonda da 1 nolu çeşit adayı ön plana çıkmıştır. Her iki çeşit adayı da tescile sunulmuştur.

\section{TEŞEKKÜR:}

$\mathrm{Bu}$ bildiri $113 \mathrm{O} 012$ nolu TÜBİTAK projesinden elde edilen verilerden hazırlanmıştır. Desteklerinden dolayı TÜBİTAK'a teşekkür ederiz.

\section{KAYNAKLAR}

Altın M 1982. Erzurum şartlarında bazı yem bitkileri ile bunların karıșımlarının değişik azot dozlarmdaki kuru ot ve ham protein verimleri ile karışımların botanik kompozisyonu. TÜBİTAK VII. Bilim Kongresi 552/TOAG 115. s: 327-362.

Anonim 1995. The Determination Of Nitrogen According To Kjeldahl Using Block Digestion And Steam Distilation. Tecator Application Note An 300, Tecator Ab Sweden, P: 1-11

Anonim 2001. Tarımsal Değerleri Ölçme Denemeleri Teknik Talimatı. Buğdaygil Yem Bitkileri Tarımsal Değerler Ölçme Denemeleri. Tc. Tar. Ve Köy. Bak. Kor. Ve Kont. Gen. Müd. Toh. Tes. Ve Sertifikasyon Mer. Müd.

Aydeniz A, Brohi AR 1991. Gübreler ve Gübreleme. C.Ü. Tokat Ziraat Fakültesi Yayınları, Yayın No. 10, Ders Kitabı 3, Tokat.

Aydin İ, Acar Z, Tosun F 1994. Samsun Ekolojik Koşullarında Bazı Çokyıllık Buğdaygil Yembitkileri Üzerinde Verim Ve Adaptasyon Çalışmaları. Tarla Bitkileri Kongresi, Cilt Iii. Çayır Mera Ve
Yembitkileri Bildirileri. S.27-31. Ege Ü.Ziraat Fak. İzmir

Düzgüneş O, Kesici T, Kavuncu O, Gürbüz F 1987. Araştırma Ve Deneme Metodları, Ankara Üniv. Zir. Fak. Yayınları, No: 295, Ankara.

George JR, Rhykerd CL, Noller CH, Dillon JE and Burns JC 1973. Effect of $\mathrm{N}$ fertilization on dry matter yield, total- $\mathrm{N}, \mathrm{N}$ recovery. and nitrate- $\mathrm{N}$ concentration of three cool -season forage gpass species. Agronomy ,1. 65: 21 1-216.

GHTB 2017. www.tarim.gov.tr 27.11.2017

Gökkuş A 1987. Değișik Islah Yöntemleri Uygulanan Ve Üstten Tohumlanan Meraların Kuru Ot Ve Ham Protein Verimleri Ile Botanik Kompozisyonları Üzerinde Araştırmalar. Doğa Türkiye Tarım Ve Orman Derg., 10 (3) : 333-342

Holt NW and Zentner RP 1985. Effects of applying inorganic fertilizer and farmyard manure on forage production and economic retums in east-central Saskatchewan. Can. J. Plant Sc1. 65 (3): 597-607.

Larson KL, Carter. JF and Vasey EH 1971. Nitrate nitrogen accumulation under bromegrass sod fertilized annually at six levels of nitrogen for fifteen years. Agronomy J. 63 (4): 527-528.

Serin Y 1996. Erzurum kıraç şartlarında yetiştirilen kılçıksız brom (Bromus inermis Leyss.)'a uygulanan değişik sıra aralığı ve gübrelerin ot ve ham protein oranına etkileri üzerinde bir araştırma. Türkiye 3. Çayır-Mer'a ve Yembitkileri Kongresi 17-19 Haziran 1996. s: 384-392, Erzurum.

Serin Y, ve Tan M 2009. Buğdaygil Yem Bitkilerinin Tarımsal Özellikleri, Ekonomik Önemleri, Taksonomileri Ve Genel Yapısal Özellikleri, Buğdaygil Ve Diğer Familyalardan Yem Bitkileri, (Avcıoğlu, R., Hatipoğlu, R., Karadağ,Y Edit.) Cilt I11. Tügem, Emre Basımevi, İzmir, S: 546-549

Smith D 1981. Forage management in the North Fourth edition. 19 chapter smooth bromegrass. Professor Emeritus of Agronomy University of Wisconsm. Madison, Wisconsin. s: 167-174.

Şehirali S 2002. Tohumluk Ve Teknolojisi. Trakya Üniv. Tekirdağ Zir. Fak. Tarla Bit. Böl. Yenilenmiş 3. Bask1, İstanbul, $464 \mathrm{~S}$.

Tosun F 1974. Baklagil Ve Buğdaygil Yem Bitkileri Kültürü, A.Ü Yayınları. Ziraat Fakültesi Yayınları No:123, Ders Kitapları Serisi No:8, Atatürk Üniversitesi Basımevi, $\quad$ Erzurum 